JACEK KULBAKA

Wydział Nauk Pedagogicznych

Akademia Pedagogiki Specjalnej im. Marii Grzegorzewskiej

$w$ Warszawie

ORCID ID: http://orcid.org/oooo-ooo1-9458-8455
Forum Pedagogiczne $9(2019) 1$

Wpłynęło: 25.12.2018 Zatwierdzono do druku: 24.04.2019 DOI: 10.21697/fp.2019.1.05

\title{
KSZTAŁCENIE SPECJALNE W DWUDZIESTOLECIU MIECZYWOJENNYM W POLSCE. TWÓRCZYNIE PEDAGOGIKI SPECJALNEJ
}

\begin{abstract}
Streszczenie: W tekście przedstawiono genezę i formy organizacyjne kształcenia specjalnego w Polsce w latach międzywojennych (1918-1939). Zwrócono szczególną uwagę na uwarunkowania towarzyszące rozwojowi szkolnictwa specjalnego (ekonomiczne, polityczne, społeczne, prawne). Intencją autora było przypomnienie i przedstawienie sylwetek osób szczególnie zasłużonych dla kształcenia specjalnego w Polsce oraz ukazanie genezy i działalności Państwowego Instytutu Pedagogiki Specjalnej (PIPS).
\end{abstract}

Słowa kluczowe: szkolnictwo specjalne; niepełnosprawność intelektualna; niewidomi; niesłyszący; społecznie niedostosowani.

\section{Wprowadzenie}

W literaturze naukowej przyjmuje się, że pierwowzorem współczesnego systemu kształcenia specjalnego w Europie i świecie były szkoły, a właściwie oddziały specjalne, założone w Paryżu w 1770 roku przez duchownego Michela de L'Epee (dla niesłyszących) i Valentina Haüy (dla niewidomych) w 1784 roku. Należałoby podkreślić, że problematyką dzieci i młodzieży moralnie zaniedbanej (społecznie niedostosowanej), łączonej z działem edukacji specjalnej w Polsce w dwudziestoleciu międzywojennym, zajęto się już w czasach renesansu, gdy powstawały placówki o charakterze wychowawczym i poprawczym (Bridewell, Amsterdam). Z kolei genezy kształcenia dzieci z niepełnosprawnością umysłową należałoby szukać w pracy naukowej i pedagogicznej Jeana Itarda, który przez kilka lat zajmował się kilkunastoletnim chłopcem, znanym jako „dzikie dziecko” lub „dziki z Aveyron”. Upowszechnienie edukacji specjalnej w XIX wieku napotykało na rozliczne bariery związane $z$ brakiem wiary i wiedzy $w$ aspekcie szans i form rehabilitacji, edukacji i generalnie ujmując uspołecznienia osób z niepełnosprawnościami. Stosunkowo 
najlepszą sieć szkół specjalnych - w sensie ilościowym i jakościowym - zorganizowano na ziemiach niemieckich, gdzie obok szkół i zakładów specjalnych zakładano przedszkola specjalne, wprowadzano w życie regulacje chroniące prawa dzieci z niepełnosprawnością, wspierano działalność społeczną i oświatową, a także organizowano badania naukowe w zakresie psychopedagogiki, pedagogiki i pedagogiki specjalnej (zwanej leczniczą). W końcu XIX wieku w najbogatszych państwach europejskich (m.in. w Anglii i we Francji) kształcenie dzieci z niepełnosprawnością nabierało szybszego tempa, co było bezsprzecznie związane dobrodziejstwami wielu osiągnięć naukowych (w tym fizjologii, medycyny, psychologii) na niwie edukacji i rehabilitacji. Belgia zasłynęła na przełomie XIX/XX wieku w metodyce kształcenia specjalnego (Owidiusz Decroly). W XIX wieku miała miejsce ewolucja w zakresie edukacji i opieki społecznej. Filantropię starano się zastępować systemowymi działaniami rządów i instytucji państwowych (Kulbaka 2012).

$\mathrm{Na}$ ziemiach polskich próby kształcenia dzieci głuchych podejmowano w czasach Stanisława Leszczyńskiego i Stanisława Augusta Poniatowskiego, ale były one bezowocne. Po upadku Rzeczypospolitej pierwszą szkołę specjalną utworzył Jakub Falkowski w Warszawie w 1817 roku (znaną przez wiele dziesięcioleci pod nazwą Instytut Głuchoniemych i Ociemniałych). W zaborach pruskim i austriackim nauczaniem niesłyszących zajęto się od lat 30. XIX wieku. Kształcenie niewidomych zaczęło się na ziemiach polskich w latach 40. i 50. XIX wieku.

W 1897 roku w Poznaniu rozpoczęła działalność pierwsza szkoła specjalna dla dzieci z niepełnosprawnością intelektualną. W zaborach austriackim i rosyjskim edukacją tej grupy dzieci zajęto się dopiero w przededniu pierwszej wojny światowej (Grodecka 1996). Wychowanie dzieci moralnie zaniedbanych (społecznie niedostosowanych) w czasach zaborów organizowano w oparciu o najlepsze rozwiązania europejskie (system progresywny), nawiązujące do postępowej myśli pedagogicznej (Pestalozzi, Fellenberg i inni). W okresie pierwszej wojny światowej podjęto starania o utworzenie sądu dla nieletnich w Warszawie. Warto przypomnieć, że pierwszy tego typu sąd rozpoczął pracę w Stanach Zjednoczonych w 1899 roku, co doprowadziło do rozwoju kurateli sądowej i ustawodawstwa dla nieletnich.

U progu niepodległości na ziemiach polskich prowadziło działalność nieco ponad 30 szkół i zakładów specjalnych, w tym: siedem dla dzieci głuchych, cztery dla niewidomych, 12 dla upośledzonych umysłowo i dziewięć dla moralnie zaniedbanych - według ówczesnej terminologii (Gasik 1990, s. 94-102; Gasik 1992, s. 21-27).

W schyłkowym okresie zaborów ważny wkład w pracę $\mathrm{z}$ dziećmi z niepełnosprawnością intelektualną wniosła Michalina Stefanowska, twórczyni oddziałów dla dzieci „mało zdolnych” przy ul. Złotej w Warszawie od 1917 roku. Oprócz tego zajmowała się przygotowaniem nauczycieli szkół specjalnych oraz badaniami dzieci podejrzanych o niedorozwój oraz metodyką kształcenia specjalnego.

Troska o dzieci z niepełnosprawnością nie uszła uwadze Rady Głównej Opiekuńczej (RGO) podczas pierwszej wojny światowej. Współpracujący z RGO Władysław Szenajch domagał się w 1916 roku systemowych działań na rzecz dzieci 
skrzywdzonych na skutek wojny (pozbawionych opieki rodzicielskiej, chorych, kalekich i niepełnosprawnych). Stanowisko powyższe popierali polscy psychiatrzy i lekarze. Podobne zadania spełniała RGO podczas drugiej wojny światowej (Przeniosło 2018; Kroll 1985).

Szczególne zainteresowanie i troskę o dziecko niepełnosprawne wykazywała dr Maria Grzegorzewska, która na forum Polskiej Ligi Nauczania w Paryżu (w maju 1918 roku) oraz w „Rocznikach Polskiej Ligi Nauczania” mówiła o konieczności zapewnienia opieki względem wszystkich dzieci, wedle ówczesnych sformułowań, „anormalnych”. Tego typu pogląd reprezentowała również prof. Józefa Joteyko, współtwórczyni Międzynarodowego Fakultetu Pedologicznego w Brukseli (Dziedzic 1970, s. 71-72; Grzegorzewska 1928).

\section{Okres międzywojenny (1918-1939)}

W 1920 roku w ramach Ministerstwa Wyznań Religijnych i Oświecenia Publicznego (dalej MWRiOP), utworzono Wydział Szkół Specjalnych i stworzono stanowisko referenta ds. szkolnictwa specjalnego. Funkcję tę powierzono dr Marii Grzegorzewskiej (Gasik 1995, s. 20-28). Bardzo energicznie w sprawy szkolnictwa specjalnego włączył się także Jan Hellmann, pierwszy Naczelnik tego Wydziału. Był on autorem wyliczeń dotyczących sytuacji i potrzeb szkolnictwa specjalnego w Polsce. Wynikało z nich, że istnieje potrzeba zorganizowania miejsc w szkołach dla (zgodnie z terminologią): 75 tys. dzieci upośledzonych umysłowo, czterech tys. dzieci głuchych, trzech tys. dzieci niewidomych, sześciu tys. dzieci chorych i kalekich oraz 1,8 tys. klas specjalnych dla 36 tys. uczniów opóźnionych w rozwoju lub zaniedbanych wychowawczo, a także 43 instytuty dla ośmiu tys. dzieci niewidomych, głuchoniemych i upośledzonych umysłowo. Ten bardzo ambitny projekt, gdyby został zrealizowany, mógłby zabezpieczyć potrzeby kształcenia dzieci i młodzieży z niepełnosprawnościami, ale nie doczekał się realizacji (Hellmann 1921). Tymczasem, jak dowodził Hellmann, brak inwestycji w szkolnictwie specjalnym skutkował zwiększeniem kosztów utrzymania osoby niepełnosprawnej przez państwo w ciągu jej całego życia. W szkołach specjalnych przebywało blisko 800 dzieci niesłyszących, ok. 200 niewidomych, ok. 150 dzieci przewlekle chorych i kalekich, a także ok. dwóch tys. dzieci z niepełnosprawnością intelektualną (Balcerek 1977, s. 119).

Dnia 7 lutego 1919 roku, na mocy dekretu o obowiązku szkolnym, ustanowiono siedmioletni okres kształcenia dla wszystkich dzieci, w tym dla dzieci niepełnosprawnych. Niestety, przepisy dekretu mówiły o tym, że: „od obowiązku szkolnego mogą być uwolnione dzieci chore fizycznie (szczególnie z gruźlicą otwartą) lub umysłowo oraz dzieci niedorozwinięte, jeżeli ich ułomności wyłączają je od pobierania nauki w szkole powszechnej. Jeśli w danej miejscowości istnieje zakład kształcenia chorych, kalek, ciemnych, głuchoniemych i niedorozwiniętych, obowiązek szkolny rozciąga się na te dzieci” (Pęcherski, Świątek 1978, s. 77). Obowiązku szkolnego 
mogły nie realizować również dzieci niepełnosprawne, jeśli zamieszkiwały dalej niż trzy kilometry od szkoły.

Tego samego dnia, 7 lutego 1919 roku, na mocy osobnego dekretu, ustanowiono pierwsze w Polsce sądy dla nieletnich. Działały one w Lublinie, Łodzi i Warszawie. Ich funkcjonowanie przyniosło większe efekty po 1932 roku, $\mathrm{z}$ chwilą wprowadzenia regulacji ustawowych. W 1932 roku wszedł w życie Kodeks karny. Do tego czasu w zakresie prawa karnego obowiązywały ustawy państw zaborczych, tj. Ustawa austriacka z 1852 roku, niemiecki Kodeks karny z 1871 roku i rosyjski Kodeks karny z 1903 roku. Na podstawie Kodeksu z 1932 roku nieletni (do 13 roku życia), którzy popełnili czyn zabroniony prawem, oraz nieletni (w wieku od 13 do 17 lat), którzy działali „bez rozeznania”, byli wychowywani przez upomnienie, oddanie pod dozór, zakład wychowawczy. Nieletni, w wieku od 13 do 17 lat, działający z rozeznaniem, kierowani byli do zakładu wychowawczo-poprawczego (Gasik 1990, s. 220-229). System postępowania z nieletnimi obejmował izby zatrzymań (48-godzinne), schroniska przy sądach dla nieletnich (maksimum do dwóch miesięcy). Powoływano kuratorów sądowych zajmujących się wywiadem środowiskowym. Nadzór nad nieletnimi sprawowało Ministerstwo Sprawiedliwości (nad zakładami wychowawczymi, poprawczymi, schroniskami, izbami zatrzymań) oraz MWRiOP. Należałoby zaznaczyć, że dział resocjalizacji nieletnich należał ilościowo do najważniejszych działów pedagogiki specjalnej w okresie międzywojennym. Do 1939 roku zorganizowano w Polsce 47 szkół, zakładów, schronisk, domów opieki dla dzieci i młodzieży moralnie zaniedbanych (społecznie niedostosowanych) i przestępczych. W Polsce nie było zakładów wychowawczo-poprawczych dla dziewcząt, wobec tego dziewczęta kierowane były przez sądy dla nieletnich do zakładów prywatnych, głównie prowadzonych przez zgromadzenia zakonne. Nadzór nad tymi placówkami pełniło Ministerstwo Sprawiedliwości, wyłączając nieliczne szkoły-internaty podległe resortowi oświaty (siedem placówek do 1939 roku) (Kalinowski, Pełka 2003).

Tematyka szkolnictwa specjalnego została uwzględniona podczas I Ogólnopolskiego Zjazdu Nauczycielskiego, zorganizowanego w Warszawie w kwietniu 1919 roku. Interesy szkolnictwa specjalnego reprezentowali: lekarz Stanisław Kopczyński, Albin Gawlik - kierownik szkoły dla dzieci upośledzonych umysłowo oraz dr Władysław Jarecki. Z ich wystąpień wynikało, że ok. sześć proc. dzieci w wieku szkolnym można było zakwalifikować jako uczestniczących w obowiązku do szkół specjalnych. W związku z tym postulowali wprowadzenie ustawowego obowiązku szkolnego oraz zorganizowanie szerokiej sieci szkół i zakładów specjalnych dla niewidomych, głuchoniemych, upośledzonych umysłowo oraz dla dzieci mało zdolnych i opóźnionych w rozwoju umysłowym. Dyskutowano także (m.in.) na temat płac, regulacji prawnych, terminologii w szkolnictwie specjalnym. W uchwałach pozjazdowych zapisano, iż: „Dzieci umysłowo lub fizycznie nienormalne lub upośledzone (mało zdolne, głuchonieme, ociemniałe, z zaburzeniami mowy, z wadami charakteru) powinny być kształcone oddzielnie 
pod kierunkiem specjalnie wykształconych kierowników" (O szkołę polską... 1919; Jamrożek 2015).

Konieczność działań systemowych w zakresie opieki nad dzieckiem niepełnosprawnym zgłaszało Polskie Towarzystwo Pediatryczne, które opracowało własny projekt rozwoju kształcenia specjalnego. Pomimo wsparcia resortu oświaty i samego ministra zdrowia Witolda Chodźki projekt nie zyskał aprobaty rządu. Trudności finansowe państwa powodowały, że problematyka dziecka niepełnosprawnego, będąca przedmiotem zainteresowania działaczy oświatowych, nauczycieli, organizacji związkowych i partii politycznych, miała charakter drugoplanowy. Również podczas I Zjazdu Psychiatrów Polskich w 1920 roku apelowano o rozbudowę szkół i oddziałów specjalnych przy szkołach powszechnych, budowę przytułków dla dzieci z objawami głuptactwa i idiotyzmu, tworzenie oddziałów dziecięcych przy zakładach psychiatrycznych (Sterling 1935; Balcerek 1977). O trudnościach organizacyjnych szkolnictwa specjalnego donosiła Maria Grzegorzewska w pierwszym numerze „Szkoły Specjalnej” z 1924 roku. Pisała wówczas „Nie rozumie społeczeństwo, że ci wszyscy, znajdujący się poza ramami życia społecznego, mogliby stać przy warsztatach pracy, jako pożyteczne jednostki i nie obciążać budżetu społecznego i nie być społeczeństwa postrachem. [...]. Państwo polskie walcząc z trudnościami finansowymi, wolno, ale stopniowo tworzy i rozwija szkoły, daje projekty i plany nowych organizacji i przygotowuje nauczycieli. Społeczeństwo jednak w tej kwestii jest w dalszym ciągu bierne. Nadal uważa, że trzeba najpierw zaspokoić w zupełności prawa do nauki i wychowania dziecka normalnego, a dopiero później zająć się sprawami anormalnych. Społeczeństwo nie chciało widzieć, co stanie się z dzieckiem usuniętym ze szkoły normalnej, które wychowa ulica, głód, nędza, poniewierka" (Grzegorzewska 1924, nr 1, s. 1-5.)

Prawa dziecka niepełnosprawnego znalazły umocowanie w konstytucji z 1921 roku, której 103 art. stanowił, iż dzieci: „bez dostatecznej opieki rodzicielskiej, zaniedbane pod względem wychowawczym, mają prawo do opieki i pomocy Państwa w zakresie oznaczonym ustawą" (Dz.U. z 1921 roku Nr 52, poz. 334). Zapowiadanej ustawy nie wydano. Dekret o obowiązku szkolnym w szkolnictwie specjalnym ukazał w innej rzeczywistości społeczno-politycznej w marcu 1956 roku (Dz.U. Z 1956 roku Nr 9, poz. 52).

W dniu 16 sierpnia 1923 roku przyjęto Ustawę o opiece społecznej. Ustawa ta w kwestii opieki nad dziećmi niepełnosprawnymi była ogólnikowa. Dotyczyła opieki nad niemowlętami, sierotami i półsierotami, dziećmi zaniedbanymi i występnymi, pominięto w niej zaś dzieci upośledzone umysłowo (Dz.U. z 1923 roku Nr 92, poz. 726).

W latach 20. XX wieku podejmowano kilka prób ustawowego uregulowania spraw opieki nad dzieckiem niepełnosprawnym. Było to jednak bezowocne. Na uwagę zasługuje jednak projekt Ministerstwa Pracy i Opieki Społecznej z 1925 roku, w którym jest mowa m.in. o potrzebie budowy 10 zakładów dla społecznie niedostosowanych, dwóch zakładów dla kalek, 10 zakładów dla głuchych, 10 zakładów 
dla dzieci ze schorzeniami gruźliczymi. Projektodawcy zgłaszali także potrzebę budowy 60 zakładów specjalnych, co miało zostać zrealizowane w latach 1926-1930.

Osobną rolę odgrywała Sekcja Szkolnictwa Specjalnego przy ZNP (powołana do życia w 1924 roku). Jej zarząd, w którym zasiadali wybitni pedagodzy, zajmował się teoretycznym pogłębieniem wiedzy nauczycieli szkół specjalnych, doskonaleniem metod nauczania, troską o materialne i prawne potrzeby nauczycieli, działalnością wydawniczą (redakcją czasopisma „Szkoła Specjalna”). W grudniu 1925 roku sekcja zorganizowała I Ogólnopolski Zjazd Nauczycielstwa Szkół Specjalnych. (Sprawozdanie z I Polskiego..., s. 69-123). W rezolucjach pozjazdowych domagano się opracowania ustawy o systemie kształcenia specjalnego, przygotowanie perspektywicznego planu rozbudowy szkół i zakładów specjalnych, zorganizowanie szkolenia zawodowego i zatrudnienia uczniów szkół specjalnych, zintensyfikowania badań nad dzieckiem. (Sprawozdanie z I Polskiego...; Kulbaka 2012, s. 137-149).

Polska należała do grupy państw, które przyjęły postanowienia uchwalonej przez Ligę Narodów tzw. deklaracji genewskiej z 1924 roku. W dokumencie tym po raz pierwszy w historii ludzkości określone zostały prawa i przywileje dziecka w zakresie kształcenia, opieki, wychowania i zabezpieczenia socjalnego (Balcerek 1990, s. 190-191). Zarówno Liga Narodów, jak i podległe jej agendy, wyspecjalizowane w zakresie opieki nad dzieckiem, nie doprowadziły w okresie międzywojennym do wypracowania całościowego systemu ochrony praw dziecka. Z ramienia Ligi Narodów w 1924 roku powstał Komitet Opieki nad Dzieckiem. W 1926 roku, na wniosek delegata $\mathrm{z}$ Hiszpanii, podjęto próbę zbadania losu dzieci niepełnosprawnych na świecie.

Ciężar działań programowo-metodycznych i szkoleniowych oraz ciężar zorganizowania i prowadzenia szkół specjalnych spoczywał w pierwszym dziesięcioleciu po odzyskaniu niepodległości na samorządach i organizacjach społecznych (Polski Komitet Pomocy Dzieciom, Polskie Towarzystwo Pediatryczne, Sekcja Szkolnictwa Specjalnego i inne). Obraz szkolnictwa specjalnego cechowały wysokie koszty utrzymania szkół oraz niska wrażliwość społeczna względem osób niepełnosprawnych.

W 1922 roku z inicjatywy Marii Grzegorzewskiej powstał Państwowy Instytut Pedagogiki Specjalnej (dalej PIPS). Geneza PIPS sięga kursów organizowanych przez magistrat $\mathrm{m}$. Łodzi i m. Warszawy w końcowych latach pierwszej wojny światowej. W 1919 roku Ministerstwo Oświaty wspólnie z Ministerstwem Zdrowia uruchomiło roczny kurs w celu przygotowania nauczycieli „dzieci niedorozwiniętych i z wadami charakteru”. W 1920 roku Tytus Benni założył Instytut Fonetyczny, zajmujący się kształceniem nauczycieli dzieci głuchych oraz specjalistów poradni logopedycznych i ortofonicznych.

W 1921 roku resort oświaty zorganizował półroczny kurs pedagogiki specjalnej, przekształcony w Państwowe Seminarium Pedagogiki Specjalnej. Ostatecznie, w lipcu 1922 roku, powstał PIPS, utworzony z połączenia tegoż seminarium z Instytutem Fonetycznym Tytusa Benniego. PIPS zajmował się przygotowaniem 
nauczycieli szkół specjalnych, prowadził działalność usługową (poradnia ortofoniczna, poradnia pedagogiki leczniczej, laboratorium psychopedagogiczne) i naukową w zakresie pedagogiki specjalnej, nazywanej w tamtym czasie pedagogiką leczniczą (Lipkowski 1983).

Światowy kryzys ekonomiczny z 1929 roku pogorszył i tak bardzo trudną sytuację gospodarczą Polski. Nastąpiło wyraźne obniżenie wskaźnika realizacji obowiązku szkolnego pośród ogółu dzieci w wieku szkolnym na terenie całego kraju, w tym także dzieci i młodzieży z niepełnosprawnością. Pomimo tego Sejm RP przyjął 11 marca 1932 roku długo oczekiwaną, ramową Ustawę szkolną „O ustroju szkolnictwa” (Ustawa jędrzejewiczowska). W art. 8 Ustawy dopuszczano odroczenie obowiązku szkolnego przez dzieci „anormalne”, jeśli w obwodzie szkolnym nie było odpowiedniej placówki. Art. 13 zawierał zapis, iż „Wychowanie i kształcenie dzieci anormalnych odbywa się w zakładach i szkołach powszechnych specjalnych, względnie w oddziałach specjalnych". W art. 33 określono zasady, na których opierało się przygotowanie zawodowe nauczycieli szkół i zakładów specjalnych. $\mathrm{Z}$ powodu braku rozporządzeń wykonawczych Ustawa $\mathrm{z} 1932$ roku nie wpłynęła na rozbudowę szkolnictwa specjalnego (Dz.U. z 1932 roku Nr 38, poz. 389).

Polityka oszczędności w dobie kryzysu gospodarczego spowodowała, że uposażenie nauczycieli szkół specjalnych zrównano z wynagrodzeniem nauczycieli szkół powszechnych. Jednocześnie, wbrew oczekiwaniom nauczycieli, zwiększono z 26 do 29 godzin tygodniowy wymiar pracy w szkołach specjalnych oraz zniesiono dodatki za pracę ponadwymiarową. Na skutek protestu środowiska nauczycielskiego MWRiOP przywróciło przywileje płacowe nauczycieli szkół specjalnych, wyższe o jedną grupę od wynagrodzenia nauczycieli szkół powszechnych (Kulbaka 2012, s. 47).

W październiku 1934 roku odbył się II Zjazd Nauczycieli Szkół Specjalnych, zorganizowany przez sekcję Szkolnictwa Specjalnego (Sprawozdanie z II Polskiego..., s. 49-253). Zjazd stał się okazją do omówienia stanu i potrzeb szkolnictwa specjalnego. Delegaci zjazdu w większości krytycznie ustosunkowali się do ustawy jędrzejewiczowskiej, wskazując na konieczność wydania odrębnej Ustawy o ustroju szkolnictwa specjalnego, przywrócenia rozwiązanego w latach 20. Wydziału Szkół Specjalnych MWRiOP, opracowania przez resort oświaty statutów szkół specjalnych, zajęcia się sprawą selekcji i kwalifikowania dzieci do placówek szkolnictwa specjalnego, usprawnienia poradnictwa zawodowego, zorganizowania klas specjalnych dla dzieci głębiej upośledzonych umysłowo. Zaproponowano nowelizację Ustawy szkolnej z 1932 roku w celu unormowania statusu i zadań szkół specjalnych, wyznaczania obowiązków państwa i organizacji samorządowych w zakładaniu i utrzymywaniu szkół specjalnych, określenia uprawnień i obowiązków nauczycieli szkół specjalnych („Szkoła Specjalna” 1934/1935, s. 49-56).

W dniu 3 sierpnia 1936 roku spełniono jeden z postulatów nauczycieli szkół specjalnych, gdy MWRiOP wydało zarządzenie w sprawie selekcji i kwalifikowania dzieci upośledzonych umysłowo do zakładów specjalnych. Do badań upoważniono 
Pracownię Psychopedagogiczną PIPS oraz wybranych nauczycieli szkół specjalnych, którzy otrzymali odpowiednie przeszkolenie w tym zakresie. Metodą testów (Bineta-Termana) diagnozowano uczniów I i II kl. szkół powszechnych, u których dopatrywano się cech niedorozwoju umysłowego. Do szkół specjalnych kwalifikowano uczniów, którzy uzyskali iloraz inteligencji w granicach od 35 do 70 jednostek. W roku szkolnym 1937/1938 do badań skierowano 6498 dzieci, zbadano 6138, zakwalifikowano do szkół specjalnych 2410 dzieci, przyjęto zaś 1831 (z braku miejsca 579 dzieci pozostało w domu lub uczęszczało do szkoły powszechnej).

W dniach od 2 do 4 października 1938 roku zebrał się I Ogólnopolski Kongres Dziecka w Warszawie. Wzięło w nim udział blisko 1,5 tys. reprezentantów świata nauki, kultury, szkolnictwa, działaczy samorządowych i reprezentantów blisko 60 organizacji społecznych. („Szkoła Specjalna” 1938/1939; „Życie Młodych” 1938, nr 11-12). Na kongresie omawiano bieżącą sytuację i przyszłość szkolnictwa specjalnego. W rezolucjach zjazdowych wnioskowano m.in. o: dalszą rozbudowę szkół i zakładów specjalnych, wyegzekwowanie i przedłużenie obowiązku szkolnego dla dzieci „anormalnych”, utworzenie zakładów wychowawczych dla dzieci i młodzieży z niepełnosprawnościami ruchowymi („kalekami”). Program reform w szkolnictwie specjalnym miał zająć od kilku do kilkunastu lat. Na temat spraw szkolnictwa specjalnego debatowano również w Wilnie na Kongresie Dziecka i Kongresie Nauczycielskim w 1939 roku (Kulbaka 2012, s. 148).

W latach 30. coraz więcej szkół specjalnych rozpoczęło działalność z inicjatywy państwa. Spośród 104 szkół podstawowych specjalnych zorganizowanych do końca roku szkolnego 1937/1938 do administracji państwowej należały 93 placówki. Dla dzieci (zgodnie z terminologią) niewidomych zorganizowano osiem szkół (678 uczniów), dla głuchoniemych 16 szkół (1311 uczniów), dla opóźnionych w rozwoju umysłowym 64 szkoły (8265 uczniów), dla moralnie zaniedbanych 16 szkół (1822 wychowanków). Łącznie w szkołach specjalnych przebywało wówczas 12076 uczniów (Szkolnictwo w liczbach 1944/45, s. 2-3).

W ramach szkół dla głuchych działały cztery szkoły samorządowe, cztery publiczne, jedna szkoła państwowa (w Instytucie Głuchoniemych i Ociemniałych w Warszawie) oraz siedem szkół prywatnych. Przy Instytucie Głuchoniemych i Ociemniałych zorganizowano jedyną w Polsce szkołę zawodową dla dzieci niesłyszących.

Szkolnictwo dla niewidomych stanowiły: jedna szkoła samorządowa w Bydgoszczy, trzy szkoły prywatne (Laski, Lwów, Bojanów k. Poznania), dwie szkoły publiczne (Łódź i Wilno) i jedna placówka państwowa przy IGO (założona W 1842 roku).

W Polsce zorganizowano także siedem zakładów dla dzieci przewlekle chorych i kalekich. Do wybuchu drugiej wojny światowej nie utworzono przedszkoli specjalnych, szkół średnich ogólnokształcących oraz szkół zawodowych. Wyjątek stanowiła eksperymentalna szkoła zawodowa prowadzona przez PIPS (Balcerek 1990; Gasik 1993, s. 9). 
W skali całego kraju potrzeby opieki nad dzieckiem z niepełnosprawnością intelektualną zaspokajano w przybliżeniu w 12 proc., nad dzieckiem społecznie niedostosowanym w 10 proc., nad dzieckiem niesłyszącym w 15 proc., z dysfunkcją wzroku w 20 proc. Istniały przy tym ogromne dysproporcje pomiędzy poszczególnymi regionami kraju. Przeszło połowa uczniów uczyła się w województwach centralnych ( 56 proc.), niemal trzecia ich część w woj. zachodnich (30 proc.), osiem proc. w woj. wschodnich i tylko sześć proc. w woj. południowych (Ryll, „Szkoła Specjalna" 1938/1939, s. 147 i n.)

Podczas wojny i okupacji ziem polskich władze niemieckie doprowadziły do zamknięcia polskich szkół specjalnych na ziemiach bezpośrednio wcielonych do III Rzeszy. Na obszarze Generalnego Gubernatorstwa los szkół specjalnych uzależniony był od ofiarności nauczycieli i od środków finansowych, których władze okupacyjne na ten cel jednak nie przewidywały. Przetrwały tylko nieliczne szkoły specjalne w: Krakowie, Lublinie, Siedlcach, Piotrkowie Trybunalskim, Laskach i szkoły w Warszawie, funkcjonujące do wybuchu Powstania Warszawskiego.

W oparciu o wyliczenia Janiny Kaźmierskiej w roku szkolnym 1943/1944 w Warszawie funkcjonowało 13 szkół specjalnych dla 1748 uczniów. Ponad 30 nauczycieli szkół specjalnych z Warszawy brało udział w tajnym nauczaniu. Wielu nauczycieli i wykładowców PIPS zmarło na skutek wycieńczenia lub zostało zamordowanych, w tym: Michał Wawrzynowski, Halina Jankowska, Witold Łuniewski, Michalina Stefanowska i Janusz Korczak (Sękowska 1998, s. 44; Gasik 1990, s. 240-247).

Polityka okupanta niemieckiego na ziemiach polskich zmierzała do eksterminacji jednostek słabych, chorych, kalekich, psychicznie chorych i niepełnosprawnych. Wielu pensjonariuszy szpitali psychiatrycznych zostało wymordowanych, m.in. w: Choroszczy, w szpitalu św. Jana Bożego w Warszawie, w Kochanówce k. Łodzi i w Kocborowie. W lublinieckim szpitalu psychiatrycznym dzieci upośledzone umysłowo zabijano przez podawanie zwiększonego stężenia luminalu (Madajczyk 1961; Mikulski 1984; Götz 2015).

Polska wyszła z wojny jako kraj wyjątkowo zniszczony. Straty majątku narodowego sięgały 38 proc. i były 13-krotnie wyższe niż dochód narodowy osiągnięty w 1938 roku. Straty szkolnictwa były jeszcze wyższe, sięgały bowiem 60 proc. przedwojennego stanu posiadania (Główny Urząd Statystyczny, Polska wliczbach, Warszawa 1962, s. 7).

Pomimo wielu niezrealizowanych potrzeb odnośnie szkolnictwa specjalnego w Drugiej Rzeczypospolitej potrzeby dziecka niepełnosprawnego, przynajmniej we wskazanym wyżej zakresie, zostały włączone w nurt polityki oświatowej państwa. Staraniem Sekcji Szkolnictwa Specjalnego wydawano „Szkołę Specjalną” (od $1924 \mathrm{roku}$ ), organizowano szkolenia, kursy i konferencje dla nauczycieli. Monopol w aspekcie przygotowania zawodowego nauczycieli szkół specjalnych spoczywał w gestii PIPS. Instytut spełniał także wiele innych funkcji, o których była już mowa (poradnictwo, działalność naukowa, metodyka kształcenia specjalnego i inne). 


\section{Twórczynie polskiej pedagogiki specjalnej}

Dokonania i wkład polskich pedagogów specjalnych z okresu Drugiej Rzeczypospolitej w rozwój teoretycznych podstaw pedagogiki specjalnej („leczniczej"), pomimo rozlicznych trudności organizacyjnych w tym zakresie, był znaczący i znalazł uznanie w innych krajach europejskich. Polska należała do grona nielicznych krajów europejskich, podobnie jak Węgry, Szwecja, Włochy, które w sposób kompleksowy zajmowały się przygotowaniem zawodowym nauczycieli uczących w szkołach specjalnych. W Polsce, podobnie jak na Węgrzech i w Szwajcarii, zorganizowano kształcenie nauczycieli wszystkich typów szkół specjalnych. We Włoszech i w Szwecji kształcono wyłącznie nauczycieli dzieci $\mathrm{z}$ niepełnosprawnością intelektualną.

Twórczynie polskiej pedagogiki specjalnej: Michalina Stefanowska, Józefa Joteyko i Maria Grzegorzewska kształciły się na Zachodzie, gdzie zdobywały tytuły naukowe i miały możliwość poznania dorobku pedagogicznego wybitnych uczonych, jak Owidiusza Decroly'ego, Édouarda Claparèda i innych. Mając możliwość kontynuowania prac naukowych na znaczących uczelniach europejskich (Sorbona), powróciły do Polski i tworzyły tutaj zręby metodyki kształcenia specjalnego oraz wzięły udział w organizacji szkół i zakładów specjalnych po 1918 roku. Przypomnienie sylwetek i osiągnięć naukowych wzmiankowanych polskich uczonych zasługuje jest cenne $\mathrm{z}$ wielu względów, także tych związanych $\mathrm{z}$ rolą kobiet $\mathrm{w}$ życiu społecznym oraz ich partycypacją $\mathrm{w}$ środowisku naukowym dotąd zarezerwowanym niemal w zupełności dla mężczyzn.

Michalina Stefanowska (1855-1939) pochodziła z Grodna, gdzie spędziła dzieciństwo i otrzymała edukację początkową. W Warszawie otrzymała dyplom nauczycielki domowej. W 1872 roku rozpoczęła pracę w czteroklasowym gimnazjum żeńskim w Łodzi w charakterze nauczycielki nauk przyrodniczych i geografii. Po 11 latach pracy nauczycielskiej rozpoczęła studia przyrodnicze. Przez dwa lata (1883-1885) studiowała zoologię w Uniwersytecie w Genewie. W 1885 roku terminowała w pracowni Hermanna Fola, gdzie zajmowała się badaniem zmysłu wzroku owadów. Po kilku latach asystentury w 1889 roku otrzymała publiczne wyróżnienie za swoje prace badawcze, $w$ tym za zbadanie i opisanie ruchu barwnika w oczach pajęczaków. Na tej podstawie przyznano jej doktorat (Grzegorzewska 1928). We Francji pogłębiała studia przyrodnicze pod kierunkiem takich uczonych, jak: T. A. Ribot, J. M. Charcot i K. Richet. Ponadto zgłębiała tajniki psychologii i psychopatologii w College de France, w Klinice Charcota w Salpêtrière oraz w Zakładzie dla Obłąkanych św. Anny. W 1897 roku zaproponowano jej pracę w Instytucie Fizjologicznym Solvay’a w Brukseli przy Wolnym Uniwersytecie Brukselskim. Propozycję tę przyjęła i przez blisko dekadę (1897-1906) zajmowała się wytężoną działalnością naukową. W 1903 roku habilitowała się na Wydziale Przyrodniczym Uniwersytetu Genewskiego (Kubeczko 1968, s. 130-131). Przygotowała i opublikowała szereg prac w języku francuskim (21) oraz jedną we współpracy z Józefą 
Joteyko w języku polskim (Asymetria czuciowa a ośrodki dla bólu) (Kubeczko 1968). Była członkinią Towarzystwa Neurologicznego w Brukseli, a następnie jego przewodniczącą. Zagranicą uczestniczyła w licznych zjazdach i kongresach naukowych. W 1907 roku przybyła do Warszawy. Prowadziła wykłady na Wyższych Kursach Naukowych z zakresu czynności układu nerwowego i narządów zmysłów (Kubeczko 1968, s. 132). Doświadczenia zawodowe, kompetencje i wielostronne zainteresowania naukowe Stefanowskiej z zakresu fizjologii i psychologii inspirowały innych pedagogów zainteresowanych modną na przełomie XIX/ XX wieku nauką o dziecku (pedologią) (Kubeczko 1968, s. 131). Od 1917 roku prowadziła wykłady z zakresu higieny odżywiania i psychofizjologii w Wolnej Wszechnicy Polskiej (do 1922 roku). W 1922 roku, na wniosek Wydziału Lekarskiego Uniwersytetu Poznańskiego, powierzono jej Katedrę Fizjologii i wykłady z zakresu fizjologii układu nerwowego i zmysłów. W międzyczasie została też asystentem w Zakładzie Antropologii tego uniwersytetu (Kubeczko 1968, s. 133).

W 1917 roku Towarzystwo Badań nad Dziećmi, powstałe z inicjatywy Jana Władysława Dawida i Anieli Szycówny, wystąpiło z propozycją założenia pierwszych oddziałów szkolnych dla dzieci mało zdolnych. Misję ich uruchomienia powierzono Michalinie Stefanowskiej jesienią 1917 roku (Radziszewska 1968, s. 134147). Pierwszy oddział dla „dzieci mało zdolnych” uruchomiono przy ul. Złotej 24. Równolegle Stefanowska zajmowała się przygotowaniem nauczycieli do pracy z dziećmi upośledzonymi umysłowo (według ówczesnej terminologii) w ramach sześciotygodniowych kursów. Z jej inicjatywy w 1918 roku odbyła się druga edycja kursu (Radziszewska 1968, s. 137). Stefanowska kierowała też „Rocznym kursem seminaryjnym dla nauczycieli dzieci mało zdolnych i z wadami charakteru" na przełomie 1919/1920 roku. Do jego prowadzenia zaprosiła grono wytrawnych pedagogów, na czele z Czesławem Babickim, Januszem Korczakiem, Józefą Joteyko, Mieczysławem Michałowiczem i Marią Grzegorzewską. Stefanowska rozpoczęła w Królestwie Polskim selekcję dzieci podejrzanych o niedorozwój umysłowy, działając w porozumieniu z inspektoratem szkolnym (Radziszewska 1968, s. 139-140). Do 1921 roku zorganizowano siedem oddziałów dla dzieci mało zdolnych. Należy podkreślić, że dzieci przebywające w oddziałach miały zapewnioną opiekę lekarską i higieniczną. Przez blisko 20 lat nadzór nad zdrowiem dzieci sprawował dr Władysław Sterling (Radziszewska, s. 146-147).

Józefa Joteyko (1866-1928) urodziła się w Poczujkach k. Kijowa. W 1896 roku, po ukończeniu studiów przyrodniczych w Paryżu, uzyskała doktorat $\mathrm{z}$ medycyny. W 1898 roku rozpoczęła asystenturę w Instytucie Fizjologicznym Solvaya, a następnie otrzymała kierownicze stanowisko w laboratorium psychofizjologicznym na uniwersytecie w Brukseli. W pracy badawczej koncentrowała się na zagadnieniach fizjologii, psychologii dziecka i pedagogiki. Była zwolenniczką badań eksperymentalnych nad dzieckiem, a także ruchu „Nowego Wychowania” i pedologii („,nauki o dziecku"). Tajniki psychologii popularyzowała z powodzeniem w toku pracy pedagogicznej w belgijskich seminariach nauczycielskich w Mons i Charleroi. 
Organizowała kursy letnie dla nauczycieli szkół „nowego typu” oraz seminaria pedagogiczne. Z inicjatywy Joteyko w 1911 roku odbył się I Międzynarodowy Kongres Pedologiczny. Wzięli w nim udział najwybitniejsi pedagodzy (Owidiusz Decroly, Adolf Ferrière, Édouard Claparède) („Ruch Pedagogiczny” 1928, nr 5, s. 129-136).

W 1912 roku zorganizowała i objęła kierownictwo na brukselskim Międzynarodowym Fakultecie Pedologicznym. Dzięki jej osobistym staraniom wśród członków fakultetu znalazło się polskie przedstawicielstwo („Szkoła Specjalna" 1927/28, nr 1). W ramach fakultetu kształcono nauczycieli na poziomie odpowiadającym programom studiów wyższych. Stosowano poglądowe metody nauczania i inicjowano samodzielne badania naukowe. Wykładowcami byli wybitni pedagodzy i naukowcy.

W czasie pierwszej wojny światowej Joteyko była współorganizatorką Polskiego Komitetu Opieki nad Polakami w okupowanej przez Niemcy Belgii. Niedługo potem zorganizowała Polską Ligę Nauczania w Paryżu, gdzie w 1916 roku powierzono jej katedrę w Collège de France. W latach 1917-1918 prowadziła prace badawcze i wykłady z zakresu pedologii i psychologii pedagogicznej na Sorbonie, a także na uniwersytecie w Lyonie. Pomimo doskonałych warunków do pracy badawczej, jakie miała we Francji, postanowiła kontynuować prace badawcze w niepodległej Polsce. W 1919 roku udała się do kraju z Marią Grzegorzewską. W osobnym transporcie pocztowym przewieziono księgozbiór i wyposażenie paryskiego laboratorium badawczego Joteyko. Początkowo prowadziła wykłady z psychologii ogólnej i pedagogiki w Państwowym Instytucie Pedagogicznym w Warszawie, a po jego likwidacji w 1925 roku rozpoczęła wykłady w Wolnej Wszechnicy Polskiej. Joteyko nie powierzono Katedry Psychologii w Uniwersytecie Warszawskim, do czego predestynowały ją dotychczasowe osiągnięcia. W 1926 roku została redaktorem pierwszego czasopisma psychologicznego „Polskie Archiwum Psychologii”, tworzonego przy współudziale Związku Nauczycielstwa Polskiego.

Osiągnięcia naukowe Joteyko sytuowały ją w gronie najwybitniejszych europejskich pedagogów i psychologów przełomu XIX/XX wieku. Jej rozliczne kontakty naukowe, doskonała znajomość języka francuskiego, a nade wszystko talent i zacięcie badawcze zaowocowały osiągnięciami naukowymi z zakresu: pobudliwości zmysłów, dwuręczności, zmęczenia w pracy i znużenia szkolnego, odczuwania bólu, wrażliwości i pamięci. Joteyko należałoby zaliczyć do pionierów psychologii rozwojowej. Była orędowniczką wykorzystywania metody testów i metody globalnej w praktyce psychologicznej i pedagogicznej. Do jej najważniejszych prac zalicza się książkę pt. La fatigue z 1920 roku (polskie tłum. Znużenie z 1930 roku) oraz Metoda testów umystowych i jej wartość naukowa z 1924 roku.

Ponadto Joteyko należała do grona innowatorów pedagogicznych. Niezmiennie wyznawała idee powszechnego i zdemokratyzowanego szkolnictwa. W 1927 roku opublikowała Postulaty szkoły twórczej na prawach struktur psychicznych. Twierdziła, że każdy typ szkoły jest społecznie użyteczny. Sprzeciwiała się twierdzeniu, jakoby 
szkoła ogólnokształcąca stała wyżej w hierarchii od szkoły zawodowej (Kupisiewicz 2006, s. 75-80).

Joteyko, obok Marii Grzegorzewskiej, należała do twórców i pierwszych wykładowców PIPS. Niestety jej stan zdrowia, pogarszający się w szybkim tempie od 1922 roku, powodował, że musiała stopniowo wycofać się z życia naukowego, choć wytężoną pracę badawczą prowadziła do końca życia. Jej warszawskie mieszkanie było zawsze otwarte dla młodych naukowców, przede wszystkim adeptów psychologii i pedagogiki.

Ze wspomnień Michaliny Stefanowskiej (Wspomnienie z życia Józefy Joteyko) wynika, że była ona osobą o wielostronnych zainteresowaniach. Pasjonowała się sztuką i architekturą, a także wszelkimi owocami ludzkiego geniuszu. Była osobą „ambitną w najszlachetniejszym tego słowa znaczeniu”. Pochłonięta w zupełności pracą badawczą świadomie nie zdecydowała się na założenie rodziny. Niewiele też podobno dbała o własne wygody i dobra materialne (Kupisiewicz 2006, s. 77).

Stefan Baley, w pracy pt. Józefa Joteyko jako psycholog eksperymentalny, napisał: „Kiedy Joteyko przeniosła sferę swych zainteresowań z fizjologii do psychologii, groziło jej niebezpieczeństwo pomieszania metod i punktów widzenia oraz celów obu nauk. (...) Pani Joteyko szczęśliwie uniknęła tego niebezpieczeństwa. W rozprawie bowiem L'expérimentation dans l'étude des phénomenes psychiques z 1906 roku stwierdziła, że „nie każdy fizjolog ma prawo uważać się za kompetentnego w kwestiach psychologicznych i że psychologowie czerpią swą wiedzę ze specyficznego źródła, mającego dla niej podstawowe znaczenie, a mianowicie z introspekcji”. Eksperyment jest zatem, według Józefy Joteyko, wręcz konieczny w psychologii, zwłaszcza w dziedzinie badań dotyczących dyspozycji i uzdolnień psychicznych. Diagnoza indywidualna, postawiona również za pomocą testów, mieć będzie duże znaczenie praktyczne dla wychowania. Temu przekonaniu dała Joteyko wyraz w rozprawach z 1908 roku La pédologie oraz Le mouvement pédologique, w których nazwała pedologię „studium psychologicznym dziecka” i zaliczyła ją do grona "nauk stosowanych”. Zalecała również, aby pedologią zajmowali się nie tylko nauczyciele-wychowawcy, lecz również lekarze. Efektem starań Józefy Joteyko był też międzynarodowy kongres pedologiczny, jaki odbył się w 1911 roku" (Kupisiewicz 2006, s. 77-78; Baley 1929).

Helena Radlińska podkreślała szczególne osiągnięcia Joteyko w dziedzinie psychologii, psychotechniki, socjotechniki i pedagogiki. Radlińska twierdziła, że Joteyko „Żyła ideałem, wczuwała się w duszę dzieci i potrzeby kraju” (Radlińska 1929).

Maria Grzegorzewska (1888-1967) urodziła się i wychowywała we wsi Wołucza (powiat Rawa Mazowiecka) w rodzinie Adolfa Grzegorzewskiego i Felicji z Bohdanowiczów Grzegorzewskiej. Ojciec zarządzał majątkiem ziemskim w Wołuczy i pobliskich miejscowościach. Grzegorzewska rozpoczęła naukę w 1900 roku w prywatnej pensji Jadwigi Kotwickiej w Warszawie. Po czterech latach przeniosła się do prywatnej szkoły (pensji) Pauliny Hawelke. Świadectwo jej 
ukończenia otrzymała w roku szkolnym 1906/1907. Na przełomie 1907/1908 roku ukończyła roczny kurs przygotowawczy do studiów uniwersyteckich na Wydziale Matematyczno-Przyrodniczym, prowadzony przez Ludwika Krzywickiego. W 1908 roku otrzymała tytuł nauczycielki domowej („domaszniaja uczitelnica”). W tym czasie rozpoczęła działalność oświatową i społeczną w środowiskach robotniczych Warszawy. Nawiązała liczne znajomości, m.in. z Heleną Radlińską, Stefanią Sempołowską, Marianem Falskim i Edwardem Abramowskim. W roku szkolnym 1909/1910 Grzegorzewska rozpoczęła studia na Wydziale Przyrodniczym Uniwersytetu Jagiellońskiego (brak immatrykulacji). W 1911 roku przerwała je z przyczyn osobistych (zła sytuacja materialna i zdrowotna). Za namową Józefy Joteyko, twórczyni Międzynarodowego Fakultetu Pedologicznego w Brukseli (1912), rozpoczęła studia zagraniczne w roku akademickim 1913/1914, początkowo w Belgii, a potem we Francji.

Zainteresowania badawcze Marii Grzegorzewskiej dotyczyły wrażeń estetycznych dzieci i młodzieży. W 1916 roku obroniła rozprawę doktorską pt. Studium na temat rozwoju uczuć estetycznych - badania z zakresu estetyki eksperymentalnej prowadzone wśród uczniów szkół brukselskich (oryg. Essai sur le developpement du sentyment estetique - recherches d'esthetique experimentale faites sur les eleves des ecoles de Bruxelles) (Tomasik 2009, s. 224-230).

W 1918 roku na łamach „Roczników Polskiej Ligi Nauczania” Grzegorzewska opublikowała tekst pt. O konieczności zorganizowania specjalnego szkolnictwa dla dzieci anormalnych $w$ Polsce. Po powrocie do Polski, o czym była już mowa, przyczyniła się do powstania PIPS, Sekcji Szkolnictwa Specjalnego, a także I Zjazdu Nauczycieli Szkół Specjalnych w 1925 roku.

W 1926 roku wydała pierwszy tom Psychologii niewidomych. W 1927 roku uczestniczyła w VII Zjeździe Psychiatrów Polskich, a także w Międzynarodowym Kongresie Ligi Nowego Wychowania w Locarno. Zwiedzała m.in. placówki dla dzieci z niepełnosprawnością intelektualną w Szwajcarii.

Od 1930 roku Grzegorzewska, wspólnie z Władysławem Radwanem, kierowała Państwowym Instytutem Nauczycielskim (dwuletni cykl kształcenia). Placówka ta, mieszcząca się we wspólnych gmachu z PIPS w Al. Ujazdowskich 20, przeznaczona była dla nauczycieli szkół powszechnych zainteresowanych rozszerzeniem kwalifikacji i kompetencji zawodowych.

Na początku lat 30. Grzegorzewska przebywała we Francji i w Belgii (1931-1932), gdzie gromadziła materiały do drugiego tomu Psychologii Niewidomych. W 1935 roku wzięła udział w Kongresie Belgijskiej Rady Nauczania, na którym przedstawiła profil i dorobek polskiego szkolnictwa specjalnego. W 1937 roku weszła w skład Wydziału Wykonawczego Międzynarodowego Towarzystwa Pedagogiki Leczniczej w Zurychu. W tym samym roku uczestniczyła w Międzynarodowym Kongresie Esperantystów w Warszawie.

W czasie wojny i okupacji Grzegorzewska pracowała jako nauczyciel szkoły specjalnej nr 177 w Warszawie przy ul. Tarczyńskiej 27. Oprócz tego pełniła dyżury 
w zakładzie dla dzieci kalekich, a także prowadziła badania selekcyjne nad dziećmi podejrzanymi o niedorozwój umysłowy. Uczestniczyła w tajnych pracach oświatowych Delegatury Rządu w Wydziale Kształcenia Nauczycieli. Współpracowała z konspiracyjną Wolną Wszechnicą Warszawską, Ludowym Instytutem Oświaty i Kultury oraz z tajnym Instytutem Pedagogicznym ZNP. Współtworzyła konspiracyjne programy samokształcenia dla nauczycieli w oflagach, uczestniczyła też w pracach programowych nad reformą systemu oświaty w powojennej Polsce. Od 1 stycznia 1942 roku była referentką działu kształcenia nauczycieli w Głównej Komisji Planowania w Departamencie Oświaty i Kultury (prowadziła tajne studium kształcenia nauczycieli). Była również członkinią Głównego Komitetu Pomocy Żydom (pseud. „Narcyza”). Z ramienia Czerwonego Krzyża wzięła udział w Powstaniu Warszawskim (w patrolu sanitarnym). Już 10 sierpnia 1944 roku, wraz z grupą ludności cywilnej, została aresztowana przy ul. Kaliskiej w Warszawie, skąd odesłano ją do obozu przejściowego. Po udanej ucieczce z pruszkowskiego Dulagu udała się do Zalesia Dolnego. Tam od jesieni 1944 roku nauczała w szkole powszechnej zorganizowanej przez Helenę i Władysława Radwanów oraz Ewę Krauze. W Zalesiu Dolnym uczestniczyła też w tajnych kompletach (Tomasik 2009).

W czasie Powstania Warszawskiego spłonęły jedyne rękopisy jej prac: gotowy drugi tom Psychologii niewidomych oraz monografia Osobowość nauczyciela. Po zakończeniu wojny podjęła osobiste starania o reaktywowanie PPIS. Instytut rozpoczął prace już w maju 1945 roku. W 1947 roku wydała pierwszy cykl Listów do młodego nauczyciela. Przewodniczyła Sekcji Szkolnictwa Specjalnego przy ZNP. Po zakończeniu wojny przez szereg lat kierowała komitetem redakcyjnym „Szkoły Specjalnej”.

Dokonania organizacyjne i naukowe Grzegorzewskiej zostały docenione przez naczelne władze państwowe. Dnia 19 sierpnia 1955 roku otrzymała Krzyż Komandorski Orderu Odrodzenia Polski. W dniu 24 stycznia 1957 roku uzyskała tytuł profesora zwyczajnego. Ponadto nadano jej tytuł honorowy Zasłużonego Nauczyciela PRL i Order Budowniczych Polski Ludowej (1959).

W 1958 roku opublikowała drugi cykl Listów do młodego nauczyciela. W latach 1958-1960 kierowała Katedrą Pedagogiki Specjalnej w Uniwersytecie Warszawskim (ustanowioną dla niej ad personam). Katedra współpracowała z PIPS i Sekcją Kompensacji Zmysłów Polskiej Akademii Nauk. Z czasem Katedra podzieliła się na Zakład Rewalidacji (Janina Doroszewska) i Resocjalizacji (Stanisław Jedlewski, Czesław Czapów).

Grzegorzewska angażowała się społecznie w działalność Polskiego Związku Głuchych i Polskiego Związku Niewidomych. W 196o roku odbyła kilkumiesięczną podróż naukową do Rzymu, Brukseli, Genewy i Yverdon, poznając z autopsji organizację szkół i zakładów specjalnych.

W 1961 roku wydała trzeci cykl Listów do młodego nauczyciela. U schyłku swego życia pisała, że „Dawniej naczelnym zadaniem pedagogiki specjalnej było wyrównywanie tych braków [...]. Obecnie pedagogika specjalna ma na celu kształcenie, 
wychowanie ogólne i zawodowe ucznia, doprowadzające go do najpełniejszej w stosunku do jego możliwości rewalidacji społecznej [...]. Przez rewalidację społeczną pedagogika specjalna rozumie nie tylko rozwój ogólny, wykształcenie ogólne i zawodowe, ale i uspołecznienie wychowanka, nie tylko takie, które ułatwi mu życie i prace w zespole, ale też takie, które umożliwi zainteresowania się dążeniami zbiorowości w tej mierze, w jakiej jego upośledzenie pozwala rozumieć funkcje jednostki w grupie oraz zadania grupy" (Lipkowski 1983, s. 31).

Maria Grzegorzewska była tyleż naukowcem (psychologiem i pedagogiem specjalnym), co społecznikiem (działalność związkowa, organizacja kursów, konferencji, zjazdów) i pedagogiem (wykłady w PIPS, UW). W Listach do młodego nauczyciela, które były w jakiejś mierze na nowo napisaną wersją zniszczonego w 1944 roku rękopisu Osobowość nauczyciela, nakreśliła ideał nauczyciela pracującego w duchu powołania i umiłowania zawodu nauczycielskiego. To dzieło było swoistym rozwinięciem „miłości dusz ludzkich”, nakreślonych w początkach XX wieku przez Jana Władysława Dawida w dziele O duszy nauczycielstwa. Wincenty Okoń w swoich wspomnieniach o Marii Grzegorzewskiej napisał, iż „Ktokolwiek zetknął się z Marią Grzegorzewską, śmiało może powiedzieć, że miał szczęście poznać tę wyjątkową postać” (Okoń 200o, s. 123).

Michalina Stefanowska, Józefa Joteyko i Maria Grzegorzewska należały do pokolenia emancypantek. Ich osiągnięcia naukowe usytuowały je w gronie najwybitniejszych naukowców przełomu XIX/XX wieku. Żadna z nich nie założyła rodziny. Swój czas dzieliły między pracę badawczą, działalność dydaktyczną i społeczną. Łączyła je ponadto wielka wrażliwość względem osób potrzebujących, zachwyt wobec wytworów natury, jak również niesłabnące zainteresowanie kulturą i sztuką. Jestem przekonany, że w wielu aspektach dokonania naukowe Stefanowskiej, Joteyko i Grzegorzewskiej nie straciły w żaden sposób na aktualności i w tym kontekście mogą stanowić (i stanowią) inspirację dla współczesnych pedagogów, pedagogów specjalnych, psychologów, historyków i innych.

\section{Bibliografia}

Balcerek M. (1977). Dzieje opieki nad dzieckiem w Polsce ze szczególnym uwzględnieniem kształcenia dzieci upośledzonych umysłowo. Warszawa: PWN.

Balcerek M. (1935). Szkolnictwo specjalne i pedagogika specjalna w pierwszej połowie $X X w$. W: Sterling D. W. Opieka lecznicza nad dzieckiem anormalnym. Warszawa. Baley S. (1929). Józefa Joteyko jako psycholog eksperymentalny. „Rocznik Pedagogiczny". T IV.

Dziedzic S. (1970). Rewalidacja upośledzonych umysłowo. Warszawa: Państwowe Zakłady Wydawnictw Szkolnych.

Gasik W. (1993). Ewolucja edukacji specjalnej. W: Edukacja osób niepełnosprawnych. Hulek A. (red.). Warszawa. 
Gasik W. (1990). Rozwój praktyki i teorii pedagogiki specjalnej w XIX i w poczatkach XX w. W: Dzieje szkolnictwa i pedagogiki specjalnej. Mauersberg S. (red.). Warszawa: PWN.

Gasik W. (1992). Rozwój teorii i praktyki pedagogiki specjalnej w Polsce w latach 1816-1945. W: Pedagogika Specjalna w Polsce. Wybrane zagadnienia z przeszłości, współczesności oraz tendencje rozwojowe. Poznański K., Eckert U. (red.). Warszawa: WSPS.

Gasik W. (1995). Życie Marii Grzegorzewskiej. Dzieciństwo i młodość - studia. W: Maria Grzegorzewska, pedagog w służbie dzieci niepełnosprawnych. Żabczyńska E. (red.). Warszawa: WSiP.

Gasik W. (1990). Praca wychowawcza $z$ moralnie zaniedbanymi i nieletnimi przestępcami w Polsce międzywojennej. W: Dzieje szkolnictwa i pedagogiki specjalnej. Mauersberg S. (red.). Warszawa: PWN.

Gasik W. (1990). Szkolnictwo specjalne w latach wojny i okupacji (1939-1945). W: Dzieje szkolnictwa i pedagogiki specjalnej. Mauersberg S. (red.). Warszawa: PWN.

Götz A. (2015). Obciążeni. Eutanazja w nazistowskich Niemczech. Wołowiec: Wydawnictwo Czarne.

Grodecka E. (1996). Historia niewidomych polskich w zarysie. Warszawa: PZN.

Grzegorzewska M., Wawrzynowski M. (1924). Zamiast programu. „Szkoła Specjalna", nr 1.

Grzegorzewska M. (1928). Józefa Joteyko. Warszawa: Komitet Uczczenia Zasług J. Joteyko.

Hellmann J. (1921). Szkoły i zakłady dla dzieci anormalnych jako kwestia społeczna oraz projekt sieci szkót specjalnych na terenach Rzeczypospolitej w związkuz materiałami statystycznymi. Warszawa.

Jamrożek W. (2015). Kongresy i zjazdy pedagogiczne w rozwoju polskiej myśli i praktyki edukacyjnej (do 1939 roku). Poznań: UAM .

Kalinowski M., Pełka M. (2003). Zarys dziejów resocjalizacji nieletnich. Warszawa: APS.

Kroll B. (1985). Rada Główna Opiekuńcza 1939-1945. Warszawa: „Książka i Wiedza”.

Kubeczko J. (1968). Michalina Stefanowska. „Szkoła Specjalna”, nr 2.

Kulbaka J. (2012). Niepełnosprawni. Z dziejów kształcenia specjalnego. Warszawa: APS.

Kupisiewicz C. Kupisiewicz M. (2006). Poczet wybitnych nauczycieli. Pułtusk: Akademia Humanistyczna im. A. Gieysztora.

Lipkowski O. (1983). Wyższa Szkoła Pedagogiki Specjalnej im. Marii Grzegorzewskiej w Warszawie 1922-1982. Warszawa: Wydawnictwo Wyższej Szkoły Pedagogiki Specjalnej im. Marii Grzegorzewskiej.

Mauersberg S. (red.). (1990). Dzieje szkolnictwa i pedagogiki specjalnej. Warszawa: PWN. 
Madajczyk C. (1961). Polityka okupanta wobec narodu polskiego. Warszawa: Wydział Propagandy i Agitacji KC PZPR.

Mikulski J. (1984). Medycyna hitlerowska w służbie III Rzeszy. Warszawa: PWN. Nekrolog Józefy Joteyko. (1927/1928). „Szkoła Specjalna”, nr 1.

Okoń W. (2000). Wizerunki sławnych pedagogów polskich. Warszawa: Żak Wydawnictwo Akademickie.

Pęcherski M., Świątek M. (1978). Organizacja oświaty w Polsce w latach 1917-1977.

Warszawa: PWN.

Po zgonie prof. dr. Józefy Joteyko. (1928). „Ruch Pedagogiczny”, nr 5, s. 129-136.

Przeniosło M., Przeniosło M. (2018). Rada Główna Opiekuńcza w latach 1918-1921.

Kielce: Wydawnictwo UJK.

Radlińska H. (1929). Maria Grzegorzewska jako pedagog. „Rocznik Pedagogiczny”. T. IV.

Radziszewska W. (1968). Jeszcze jedna rocznica w historii szkolnictwa specjalnego dla dzieci upośledzonych w Warszawie (1917-1922). „Szkoła Specjalna”, nr 2.

Ryll H. (1938/1939). Stan szkolnictwa specjalnego w ostatnim piętnastoleciu. „Szkoła Specjalna”, nr 3, s. 147-157.

Sękowska Z. (1998). Wprowadzenie do pedagogiki specjalnej. Warszawa: Wydawnictwo WSPS.

Tomasik E. (2009). Maria Grzegorzewska - człowiek i dzieło. „Przegląd Historyczno-Oświatowy", nr 1-2.

\section{Źródła drukowane}

O szkołę polską. Pierwszy Ogólnopolski Wielki Zjazd Nauczycielski 14, 15, 16 i 17 kwietnia 1919 r. $w$ Warszawie. (1919). Lwów-Warszawa.

Szkolnictwo w liczbach 1944/1945. Prace Biura Badań i Statystyki Ministerstwa Oświaty. (1946). Falski M. (red.). Warszawa.

Sprawozdanie z I Polskiego Zjazdu Nauczycieli Szkół Specjalnych. (1926). „Szkoła Specjalna", nr 2, s. 69-123.

Sprawozdanie z II Polskiego Zjazdu Nauczycieli Szkół Specjalnych. (1934/1935). „Szkoła Specjalna”, nr 2-4, s. 49 i in.

\section{Dzienniki Ustaw i Dzienniki Urzędowe}

Dz.U. z 1921 roku Nr 52, poz. 334. (Konstytucja z 17 marca 1921 roku).

Dz.U. z 1923 roku Nr 92, poz. 726. (Ustawa o opiece społecznej).

Dz.U. z 1932 roku Nr 38, poz. 389. (Ustawa szkolna Janusza Jędrzejewicza z 11 marca $1932 \mathrm{roku})$.

Dz.U. z 1956 roku Nr 9, poz. 52. (Dekret z dnia 23 marca 1956 roku o obowiązku szkolnym). 


\title{
SPECIAL EDUCATION IN POLAND BETWEEN 1918 AND 1939: FEMALE FOUNDERS OF SPECIAL EDUCATION
}

\begin{abstract}
The text presents the origin and organizational forms of special education in Poland in the interwar period (1918-1939) with a particular attention to the conditions during the development of special education (economic, political, social, legal). The author presents the most distinguished individuals who played the key role in the development of special education in Poland. The origin and activities of the Institute of Special Education (PIPS) are also discussed in this paper.
\end{abstract}

Keywords: special education; mental disability; blind; deaf; socially unadjusted.

Jacek Kulbaka - doktor habilitowany, profesor Akademii Pedagogiki Specjalnej im. Marii Grzegorzewskiej w Warszawie, wykładowca akademicki (historia wychowania i historia kształcenia specjalnego), nauczyciel gimnazjalny (historia). Autor artykułów i książek z zakresu historii kształcenia specjalnego, historii wychowania i historii Lubelszczyzny. Adres e-mailowy: akabluk@wp.pl. 